\title{
Carbon and nitrogen stable isotope compositions of organic matter in marine sediment cores from the Abrolhos region: indicators of sources and preservation
}

Josè Roberto Bispo de Souza ${ }^{1}$

Alexandre Barreto Costa ${ }^{1}$

Antônio Expedito Gomes de Azevedo ${ }^{1}$

Tárcio Henrique Ribeiro dos Santos ${ }^{1}$

Saulo Spano'

Carlos Alessandre Domingos Lentini ${ }^{1}$

Tito José Bonabamba ${ }^{2}$

Rodrigo de Oliveira Silva ${ }^{2}$

Etelvino Henrique Novotny ${ }^{3}$

Maria do Rosário Zucchi ${ }^{1 *}$

'Departamento de Física da Terra e do Meio Ambiente, Instituto de Física da Universidade

Federal da Bahia (UFBA) - Salvador (BA), Brazil.

${ }^{2}$ Instituto de Física de São Carlos da Universidade de São Paulo (USP) - São Paulo (SP), Brazil.

${ }^{3}$ Embrapa Solos - Rio de Janeiro (RJ), Brazil.

*Corresponding author: mrzucchi@ufba.br

\begin{abstract}
Organic matter is an important source of information on the transport and consolidation processes of sediments. In this study, the isotopes of carbon and nitrogen $\left(\delta^{13} \mathrm{C}\right.$ and $\left.\delta^{15} \mathrm{~N}\right)$, total organic carbon (TOC), total nitrogen, carbon/nitrogen $(\mathrm{C} / \mathrm{N})$ ratio, and ${ }^{13} \mathrm{C}-\mathrm{NMR}$ were utilized to understand the origin and behavior of organic material in the Abrolhos region. It were analyzed nine sediment cores taken from a mangrove, a channel between the mainland and the coral reefs. The average value of the $\mathrm{C} / \mathrm{N}$ ratio in the mangrove was 18 , which characterizes purely terrigenous areas. For the reefs, the average value of the $\mathrm{C} / \mathrm{N}$ ratio was 8 , which is characteristic of marine and coastal regions. For the sediment cores taken from the channel, the average value of the $\mathrm{C} / \mathrm{N}$ ratio was 10 , a typical value of areas under the influence of mangroves. The mean values of $\delta^{13} \mathrm{C}$ were $-26.9 \%$ for the mangrove, $-20.7 \%$ for the channel region, and $-18.2 \%$ for the reefs. This variation is associated with the main source of organic matter, which in the mangrove is derived from vascular plants (mainly C3 metabolism) and for the reefs is derived from phytoplankton. The ${ }^{13} \mathrm{C}-\mathrm{NMR}$ results corroborate the isotopic and elemental analyses. The analyses of these cores indicate that the anthropogenic influence on the coast did not significantly alter the composition of the material that has been deposited in about the last 80 years in the region of study.
\end{abstract}

Keywords: Abrolhos, marine sediments, ${ }^{13} \mathrm{C}-\mathrm{NMR}$, stable isotope.

\section{Resumo}

A matéria orgânica é uma fonte de informação importante nos processos de transporte e consolidação de sedimentos. Neste estudo, foram utilizados isótopos de carbono e de nitrogênio $\left(\delta^{13} \mathrm{C}\right.$ e $\left.\delta^{15} \mathrm{~N}\right)$, carbono orgânico total (TOC), nitrogênio total, razão carbono/nitrogênio (C/N) e ${ }^{13} \mathrm{C}-\mathrm{NMR}$ para entender a origem e o comportamento do material orgânico na região de Abrolhos. Foram analisados nove testemunhos de sedimentos coletados em um manguezal, em um canal e em recifes de corais. O valor médio da razão $\mathrm{C} / \mathrm{N}$ no manguezal foi de 18, o que caracteriza áreas puramente terrígenas. Nos recifes, esse valor foi de 8 , característico de regiões marinhas e costeiras, e, nos testemunhos de sedimentos coletados no canal, foi de 10, um valor típico de áreas sob a influência de manguezais. O valor médio de $\delta^{13} \mathrm{C}$ foi de $-26,9 \%$ para o manguezal, $-20,7 \%$ para a região do canal e $-18,2 \%$ para os recifes. Essa variação é associada com a principal fonte de matéria orgânica, 
a qual, no manguezal, é derivada de plantas vasculares (principalmente de metabolismo C3) e, nos recifes, é derivada de fitoplâncton. Os resultados de ${ }^{13} \mathrm{C}-\mathrm{NMR}$ corroboram as análises isotópicas e elementais. As análises dos testemunhos indicam que a influência antropogênica da região costeira não altera significantemente a composição do material que tem sido depositado nos últimos 80 anos na região estudada.

Palavras-chave: Abrolhos, sedimentos marinhos, RMN, isótopos estáveis.

\section{INTRODUCTION}

Carbon in the ocean is found in various forms. The major forms are dissolved inorganic and organic carbon, particulate organic carbon, and the carbon in sediments and primary producers (phytoplankton, algae, and vascular plants). Most of the organic carbon produced in the oceans is degraded, and only a small part is stored in marine sediments. The organic matter $(\mathrm{OM})$ in marine sediments should reflect the isotopic composition of its source of carbon, which in most cases are phytoplankton. In coastal areas, however, beyond the phytoplankton, there is the influence of terrestrial material carried mainly by rivers and/or made available by human interventions. The elemental and isotopic analyses of organic carbon show that the greatest contribution to this deposition comes from phytoplankton. This indicates that most of the organic carbon of terrestrial origin is degraded in the ocean before being deposited as sediment (Hedges et al. 1997).

Deines (1980) compiled a data collection of isotopic values for marine sediments, resulting in a bimodal distribution, where the mode with highest isotopic values was between -10 and $-19 \%$, reflecting the isotopic composition of plants and organisms from coastal regions (Martinelli et al. 2009).

The carbon/nitrogen $(\mathrm{C} / \mathrm{N})$ ratio has been used as a parameter to assess the relative influence of marine and terrestrial OM in some ecosystems (Guo et al. 2004, Usui et al. 2006, Nagel et al. 2009). Some authors suggest different values of the $\mathrm{C} / \mathrm{N}$ ratio according to the origin of the OM. Saito and colleagues (1989) suggested a ratio greater than 20 for a terrestrial origin and between 5 and 7 for a marine source. Stein (1991) demonstrated that values below 10 indicate a marine origin and that values of approximately 10 indicate components of both marine and terrestrial origins in the sediment.

With isotopic analysis, it is possible to determine the sources of OM, whether terrestrial, marine, or urban, and thus it is possible to assess the anthropogenic impacts in the studied area, as in the case of Babitonga Bay (Santa Catarina, Brazil) (Barros et al. 2010). In this sense, the application of carbon and nitrogen stable isotope analyses allows us to trace the origin of the OM that causes the increase in the isotope values of $\delta^{13} \mathrm{C}$ and $\delta^{15} \mathrm{~N}$ in suspended sediment. The isotopic enrichment may be due to contamination by untreated sewage or proximity to large estuaries (Sampaio et al. 2010). It may also be due to the presence of ancient carbon (kerogen) and primary production. In the Gulf of Thailand, isotopic enrichment due to the presence of algae has been previously detected (Meksumpun et al. 2005). Studies in the Adriatic Sea using organic carbon, total nitrogen, and $\mathrm{C} / \mathrm{N}$ ratio and isotope analyses, $\delta^{13} \mathrm{C}$ and $\delta^{15} \mathrm{~N}$, in surface sediments and suspended particulate matter identified possible sources of OM (Tesi et al. 2007). Another study reports that the OM concentration in sediments of terrestrial origin decreases significantly with increasing distance from the mouth, which is an important outcome for the study of OM flow (Ogrinc et al. 2005).

Solid-state ${ }^{13} \mathrm{C}$ NMR allows for the study of $\mathrm{OM}$ in marine sediments with respect to its composition and quality, and it can identify the organic groups present in the sample without the use of solvents, as the use of solvents does not guarantee the extraction of all OM from the sediment matrix. Solid-state ${ }^{13} \mathrm{C} N M R$, together with cross polarization (CP) and magic angle spinning (MAS) techniques, can be used to determine carbon forms such as alkyl, methoxyl, alkyl O-substituted, aromatic, aromatic O-substituted, and carbonyl present in a sample of OM (Hatcher et al. 1980, Hedges \& Oades, 1997).

In this study, elemental analysis of isotopic ratio (EAIRMS) and solid-state ${ }^{13} \mathrm{C}$ NMR were used to characterize the OM present in the environments of coastal and marine mangroves. With these data, it is possible to ascertain the origin of $\mathrm{OM}$ and the mechanisms that regulate the distribution of OM in sediments from Abrolhos region. 


\section{MATERIALS AND METHODS}

\subsection{Sampling and study area}

Nine sediment cores have been collected in the region that includes the arc of Abrolhos, near Caravelas (Figure 1). The samples were collected using pipes with a diameter of $75 \mathrm{~mm}$ and a length of $50 \mathrm{~cm}$. After collection, the samples were transported vertically, wrapped in ice. In the laboratory, the sediment cores were stored at $-20^{\circ} \mathrm{C}$. The cores were divided into slices $2 \mathrm{~cm}$ thick, freeze dried, soaked, and then stored in petri dishes.

The current direction in the coastal reef region of the inner arc of the Abrolhos Bank is clearly bimodal and preferentially oriented in the NE-SW direction, parallel to the coast. According to Teixeira (2006), the average magnitude of the currents studied in the channel that separates the mainland reef ranges from 10 to $25 \mathrm{~cm} / \mathrm{s}$.

The driest period, from May to October, has an average monthly rainfall of $110.9 \mathrm{~mm}$. The rainy season is characterized by NE winds with an occurrence of $39 \%$, while the dry season is characterized by $\mathrm{S}$ and SE winds with an occurrence of $40 \%$. The largest mean significant height and wave periods recorded in five years (i.e., 2001 to 2005) in the region were $0.4 \mathrm{~m}$ and $5 \mathrm{~s}$, respectively. The tide in this region is classified as semidiurnal, and the amplitudes of the tidal main harmonic components are 91 and $38 \mathrm{~cm}$ (Teixeira 2006).

The mangrove areas have chosen for evaluation taking into consideration human presence. After evaluating major mining activity in the region, an unexplored area for shellfish was selected. The Abrolhos arc of coral reefs is separated from the mainland by the canal to the SE with less than $20 \mathrm{~m}$ in depth. Near the coastline, there are sandy-muddy banks, while the nearby reef substrate is composed of sand, gravel, and mud. The composition in this material is variable, and it depends on its proximity to the mainland or of the reef formations. Across the reef are filamentous and calcareous algae. Areas with macroalgae are found scattered on the reef as they are on octocorals. The examined sediment varies from mud to gravel with fragments of various marine organisms. The most frequent reef algae are filamentous, and calcareous algae and macro algae occur occasionally. The existence of shallows around the reef provides damping of the wave train that elapses in the area, which influences the amount of suspended sediment in the water column.
Figure 1

Abrolhos region map with the location of the collected cores.

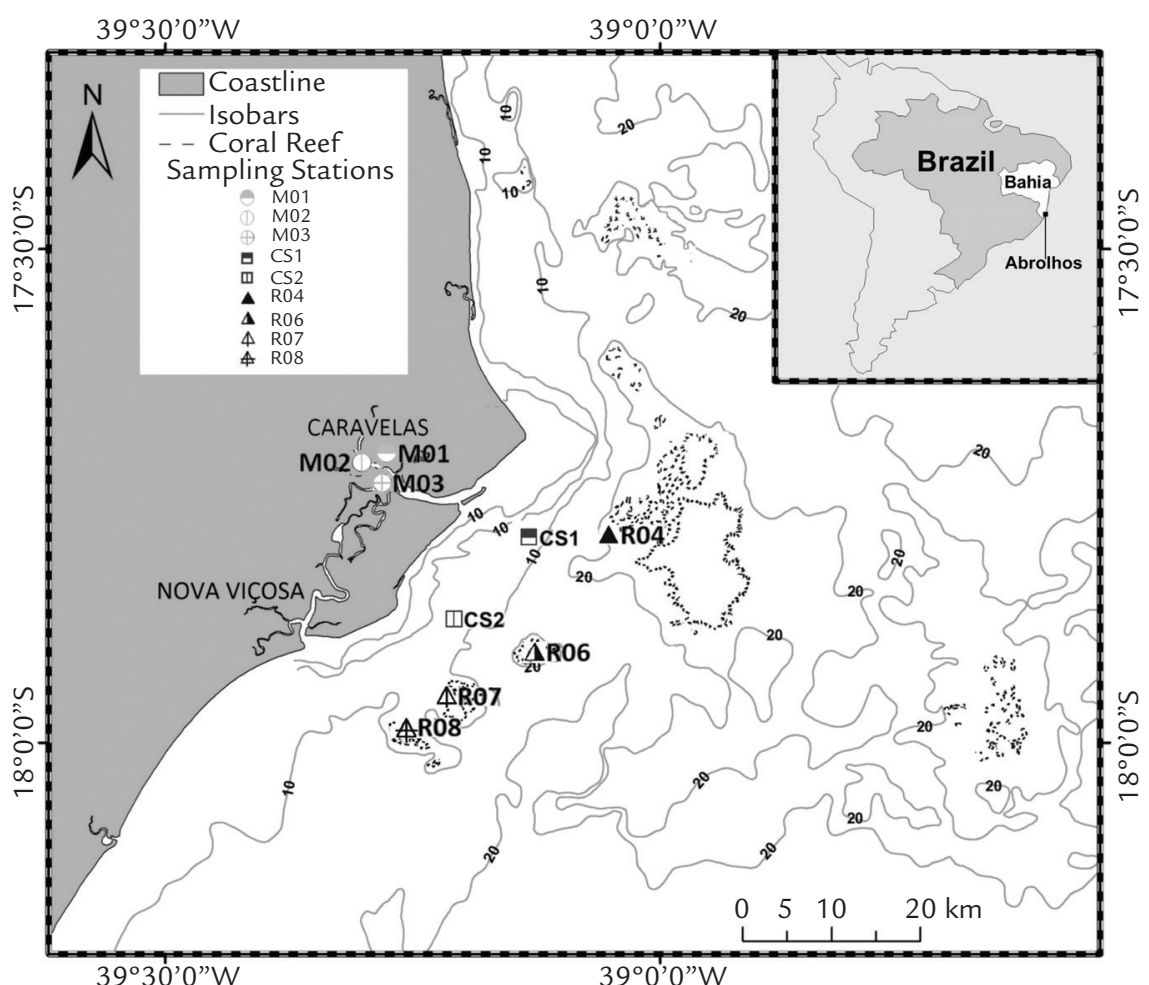

Mangroves, in North to South order: M01, M02, M03. Coral reefs in North to South order; the stations are Pedra de Leste (R04), Sebastião Gomes (R06), Coroa Vermelha (R07), and Nova Viçosa (R08). Channel, referenced by the Oceanographic buoys 106 (CS1) and 506 (CS02). 


\subsection{Elemental analysis and isotopic ratio}

Approximately $0.5 \mathrm{~g}$ of each sample was treated with $10 \mathrm{~mL}$ of $1 \mathrm{~mol} / \mathrm{L}$ hydrochloric acid $(\mathrm{HCl})$ to remove carbonate. The sample was washed and dried at temperatures between 35 and $50^{\circ} \mathrm{C}$ (Ryba \& Burgess, 2002; Burone et al. 2003). Approximately $8 \mathrm{mg}$ of the dry sample was weighed in tin capsules to perform an EA-IRMS using a Costech elemental analyzer coupled to a Thermo Finnigan Delta Plus mass spectrometer. The calibration was checked by a standard reference marine sediment certified by NIST (National Institute of Standards and Technology), under the $1941 \mathrm{~b}$ identification number, which was subjected to the same treatment process of the samples. The isotopic values were referenced with respect to two references that were certified by the International Atomic Energy Agency: USGS-40 and USGS-

\subsection{Solid-state ${ }^{13} \mathrm{C}$ NMR}

For the analysis, we weighed $5 \mathrm{~g}$ of each dry sediment sample for treatment with $1 \mathrm{~mol} / \mathrm{L}$ hydrochloric acid $(\mathrm{HCl})$ and $10 \%(\mathrm{v} / \mathrm{v})$ hydrofluoric acid $(\mathrm{HF})$. The samples were placed in a Teflon beaker, and $50 \mathrm{~mL}$ of $\mathrm{HCl}$ was added to remove carbonates. The samples were left for $24 \mathrm{~h}$ to complete the reaction and the deposition at the bottom of the container to remove the supernatant liquid. Then, we added $25 \mathrm{~mL}$ of $\mathrm{HCl}$ and $25 \mathrm{~mL}$ of $\mathrm{HF}$ to remove silicates. Again, we left it for $24 \mathrm{~h}$ and removed the supernatant. The samples were washed

\section{RESULTS AND DISCUSSION}

\subsection{Elemental and isotopic analysis}

The total organic carbon (TOC) values were fairly homogeneous throughout the experiment (Figure 2), although a decrease was observed in TOC in the bottom of sediment core M02. R04 contained a higher amount of TOC, which can probably be related to the location of the sediment core. Among all the stations, this sample was the closest to the reef, which is rich in marine biodiversity. In R08, the TOC variation throughout the sample has a higher dispersion of values when compared with other stations. The dispersion may be related to the natural burial of sediments containing pieces of seaweed in the process of sediment deposition.
41. The final result was reported with $\delta^{13} \mathrm{C}(\%)$ relative to PDB and $\delta^{15} \mathrm{~N}(\%)$ relative to atmospheric nitrogen, according to

$\delta X=\frac{\mathrm{R}_{\text {sample }}-\mathrm{R}_{\text {standard }}}{\mathrm{R}_{\text {standard }}} \times 1,000(\%)$,

where $\mathrm{X}=\mathrm{C}$ (carbon) or $\mathrm{N}$ (nitrogen) and $\mathrm{R}={ }^{13} \mathrm{C} /{ }^{12} \mathrm{C}$ for carbon and ${ }^{15} \mathrm{~N} /{ }^{14} \mathrm{~N}$ for nitrogen. The analysis of several standards during the measurements and the precision for the analytical process of preparation and measurement was approximately $0.05 \%$. The errors associated with the determination of the mass were approximately $5 \%$, while values for the isotopes $\delta^{13} \mathrm{C}\left(\%\right.$ o) and $\delta^{15} \mathrm{~N}(\%)$ were $\pm 0.3 \%$.

three times with deionized water to remove waste; then they were frozen and lyophilized (Gélinas et al. 2001).

The measurements in the sediments were made using a Unit Inova Varian spectrometer operating at 400 and 100.5 MHz for ${ }^{1} \mathrm{H}$ and ${ }^{13} \mathrm{C}$, respectively. The spectrum was acquired using the CP/MAS method, with a linear variation of radio frequency (ramped-CP). The decoupling power of the applied field during signal acquisition was $60 \mathrm{kHz}$. The contact time was $1 \mathrm{~ms}$ and the frequency of rotation was $6 \mathrm{kHz}$.

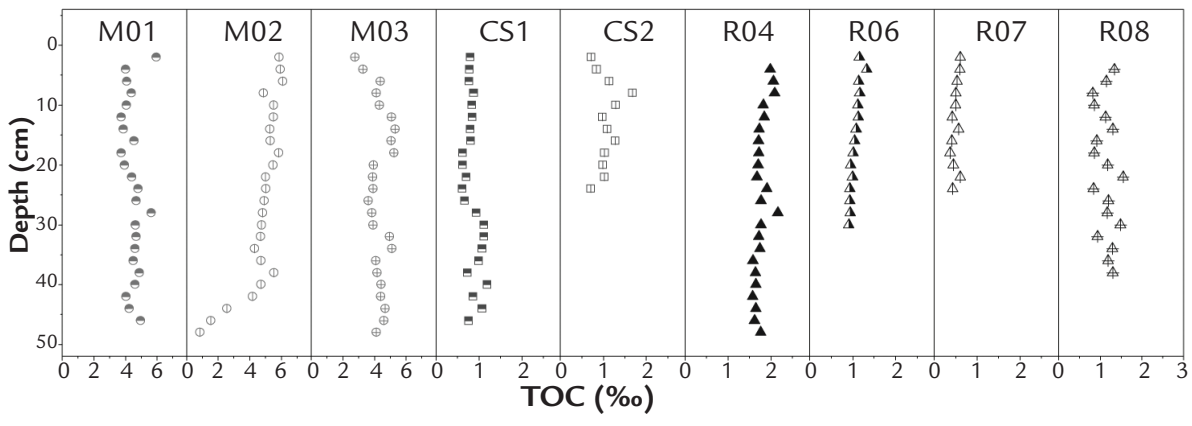

TOC: total organic carbon; $\mathrm{N}$ : nitrogen; $\mathrm{C} / \mathrm{N}$ : carbon/nitrogen ratio; $\delta^{13} \mathrm{C}$ : isotopic carbon; $\delta^{15} \mathrm{~N}$ : isotopic nitrogen. Mangroves, in North to South order: M01, M02, M03. Channel, referenced by the Oceanographic buoys 106 (CS1) and 506 (CS02). Coral reefs in North to South order; the stations are Pedra de Leste (R04), Sebastião Gomes (R06), Coroa Vermelha (R07), and Nova Viçosa (R08).
The station M02 showed (Figure 3) a variation similar to that experienced in the analysis of TOC. The result is related to the possible change in the deposited material.

The sediment core M02 illustrates a change in the behavior of all parameters, indicating a likely change in the origin of the sediment; it appears that the terrestrial feature increases from a depth of $40 \mathrm{~cm}$ to the top $(0 \mathrm{~cm})$. Considering the sedimentation rate for the region of $6.68 \mathrm{~mm} / \mathrm{y}$ (Netto 2008), this change would have happened in the last 60 years.

The values for TOC and total $\mathrm{N}$ over the sediment cores from the channel were more homogeneous for CS1
Figure 2

Profiles of total organic carbon in the cores. 
than CS2. The values are generally much smaller than those found in the sediment cores from the mangrove.

The values of total nitrogen in the sediment core R04 are slightly larger at the top of the sample, decreasing to approximately constant values at $12 \mathrm{~cm}$ from the top of the sediment core. These values are on average two times higher than those found in the sediment cores R06 and R08. The differences observed in $\mathrm{R} 04$, in relation to other reef areas, may be related to the characteristics of the site sampled. R04 has a depth of $12 \mathrm{~m}$ plus the proximity of the reef structure. This enables the deposition of sediment rich in matter from marine organisms and plants. The value found for the sediment core R07 is much lower than the others and may be related to its position. In R08, the variation of $\mathrm{N}(\%)$ over the sample has a higher dispersion of values when compared with the other studied stations. As with TOC, the variation of $\mathrm{N}(\%)$ could be correlated with the burial of sediments with different amounts of OM, which is possibly explained by the shock waves that release fragments of macroalgae and other marine organisms.

The $\mathrm{C} / \mathrm{N}$ values found in the samples from mangrove areas (Figure 4) are typical of vascular plants, mainly utilizing C3 metabolism, observed in mangrove environments (Sampaio et al. 2010).

The average values of $\mathrm{C} / \mathrm{N}$ found in the samples from that region of the channel are a feature of a transitional environment, with intermediate values between the mangrove and reef environment. On the other hand, the $\mathrm{C} / \mathrm{N}$ values for the reefs are typical of marine environments (Denies 1980).

The values of $\delta^{13} \mathrm{C}(\%)$ (Figure 5) found for the mangroves are very similar and homogeneous to the whole sediment core; however, the M02 sample had an enrichment
Figure 3

Profiles of total nitrogen in the cores.

Figure 4

Profiles of nitrogen/carbon ratio in the cores.

Figure 5

Profiles of $\delta^{13} \mathrm{C}$ values in the cores.

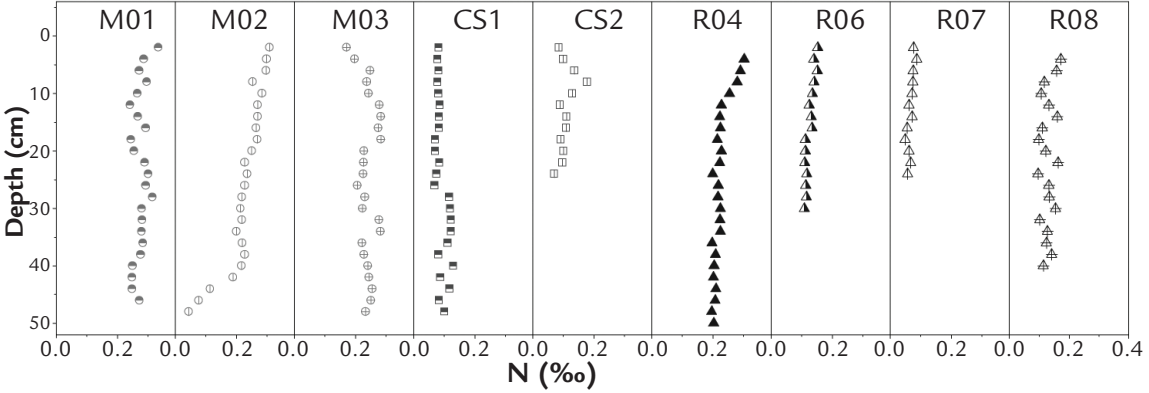

TOC: total organic carbon; $\mathrm{N}$ : nitrogen; $\mathrm{C} / \mathrm{N}$ : carbon/nitrogen ratio; $\delta^{13} \mathrm{C}$ : isotopic carbon; $\delta^{15} \mathrm{~N}$ : isotopic nitrogen. Mangroves, in North to South order: M01, M02, M03. Channel, referenced by the Oceanographic buoys 106 (CS1) and 506 (CS02). Coral reefs in North to South order; the stations are Pedra de Leste (R04), Sebastião Gomes (R06), Coroa Vermelha (R07), and Nova Viçosa (R08).

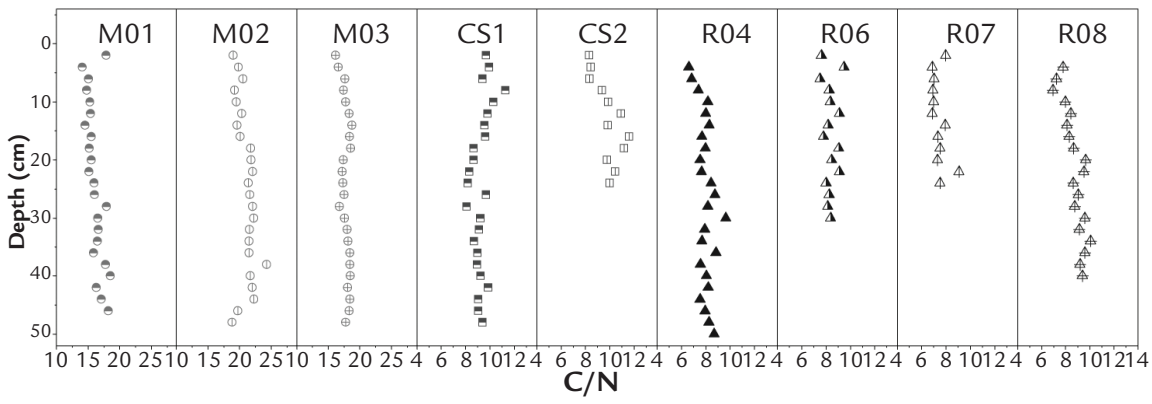

TOC: total organic carbon; $\mathrm{N}$ : nitrogen; $\mathrm{C} / \mathrm{N}$ : carbon/nitrogen ratio; $\delta^{13} \mathrm{C}$ : isotopic carbon; $\delta^{15} \mathrm{~N}$ : isotopic nitrogen. Mangroves, in North to South order: M01, M02, M03. Channel, referenced by the Oceanographic buoys 106 (CS1) and 506 (CS02). Coral reefs in North to South order; the stations are Pedra de Leste (R04), Sebastião Gomes (R06), Coroa Vermelha (R07), and Nova Viçosa (R08).

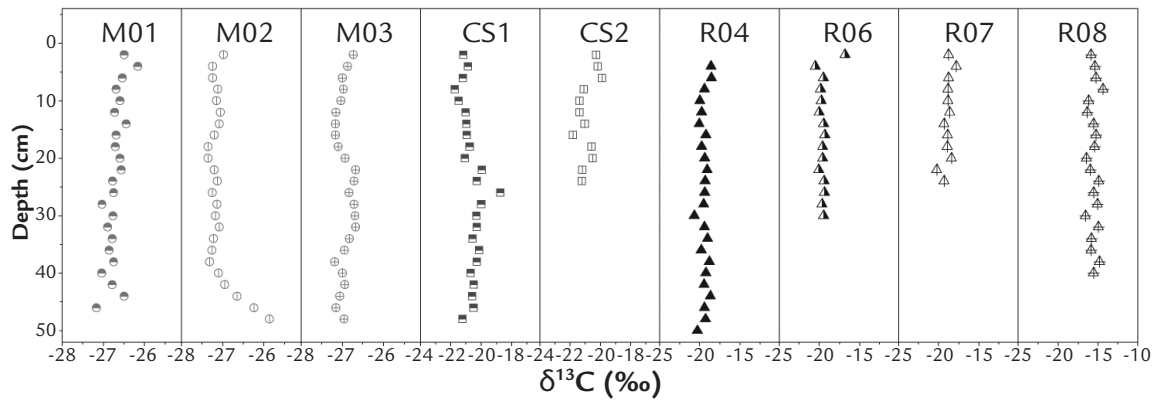

TOC: total organic carbon; $\mathrm{N}$ : nitrogen; $\mathrm{C} / \mathrm{N}$ : carbon/nitrogen ratio; $\delta^{13} \mathrm{C}$ : isotopic carbon; $\delta^{15} \mathrm{~N}$ : isotopic nitrogen. Mangroves, in North to South order: M01, M02, M03. Channel, referenced by the Oceanographic buoys 106 (CS1) and 506 (CS02). Coral reefs in North to South order; the stations are Pedra de Leste (R04), Sebastião Gomes (R06), Coroa Vermelha (R07), and Nova Viçosa (R08). 
that accompanies the decrease of TOC $(\%)$. The recorded values for the channel (CS1 and CS2) are intermediate to those observed for the environment of the mangrove and reef, corroborating the results of the marine and terrestrial OM contribution to the environment. Sediment core R08 contained a higher value of $\delta^{13} \mathrm{C}(\%)$, which can be explained by the presence of a large amount of macroalgae at the site, enriching the isotope values of carbon.

The $\delta^{15} \mathrm{~N}$ values (\%o) for the mangrove cores are very similar and homogeneous for the whole sediment core, but with an enrichment for M02, in contrast to data obtained for $\delta^{13} \mathrm{C}(\%)$ (Figure 6).

The $\delta^{15} \mathrm{~N}(\%)$ values for the channel are heterogeneous throughout the sediment core. Among the nitrogen isotopic results, the variation of $\delta^{15} \mathrm{~N}(\%)$ throughout the sample in core R08 has a highest dispersion of values when compared with other stations, and it is also the poorest between reefs cores. This variation and the enrichment of $\delta^{13} \mathrm{C}(\%)$ obtained in the analysis is explained by the large presence of macro algae in the vicinity of this core.

Table 1 summarizes the results found in the analysis of the sediment cores of mangroves (M01, M02, and M03), channels (CS1 and CS2), and reefs (R04, R06, R07, and R08) with EA-IRMS and the average, minimum, maximum, and standard deviation (SD) of TOC, $\mathrm{N}, \mathrm{C} / \mathrm{N}, \delta^{13} \mathrm{C}(\%)$, and $\delta^{15} \mathrm{~N}$ $(\%)$. The minimum and maximum values of the averages of the $\delta^{13} \mathrm{C}$ and $\delta^{15} \mathrm{~N}$ compositions of $\mathrm{OM}$ varied from $-27.1 \%$ to $-15.5 \%$ and from $+0.5 \%$ o to $+3.9 \%$, respectively, and the

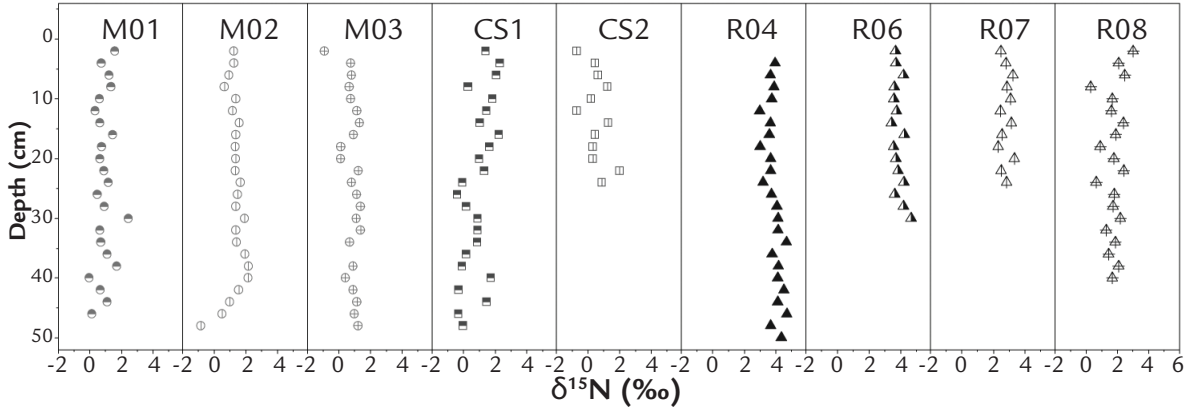

TOC: total organic carbon; $\mathrm{N}$ : nitrogen; $\mathrm{C} / \mathrm{N}$ : carbon/nitrogen ratio; $\delta^{13} \mathrm{C}$ : isotopic carbon; $\delta^{15} \mathrm{~N}$ : isotopic nitrogen. Mangroves, in North to South order: M01, M02, M03. Channel, referenced by the Oceanographic buoys 106 (CS1) and 506 (CS02). Coral reefs in North to South order; the stations are Pedra de Leste (R04), Sebastião Gomes (R06), Coroa Vermelha (R07), and Nova Viçosa (R08).

\begin{tabular}{|c|c|c|c|c|c|c|c|c|c|c|}
\hline & & M1 & M2 & M3 & CS1 & CS2 & R04 & R06 & R07 & R08 \\
\hline \multirow{4}{*}{ TOC (\%) } & Mean & 4.48 & 4.72 & 4.30 & 0.85 & 1.06 & 1.78 & 1.06 & 1.13 & 0.50 \\
\hline & Min & 3.72 & 0.83 & 2.75 & 0.61 & 0.71 & 1.58 & 0.91 & 0.82 & 0.37 \\
\hline & Max & 5.96 & 6.10 & 5.30 & 1.19 & 1.68 & 2.16 & 1.33 & 1.55 & 0.62 \\
\hline & SD & 0.56 & 1.32 & 0.63 & 0.17 & 0.27 & 0.16 & 0.12 & 0.22 & 0.08 \\
\hline \multirow{4}{*}{$\mathrm{N}(\%)$} & Mean & 0.28 & 0.23 & 0.24 & 0.09 & 0.11 & 0.23 & 0.13 & 0.13 & 0.07 \\
\hline & Min & 0.24 & 0.04 & 0.17 & 0.07 & 0.07 & 0.20 & 0.11 & 0.10 & 0.05 \\
\hline & Max & 0.33 & 0.31 & 0.28 & 0.13 & 0.18 & 0.30 & 0.15 & 0.17 & 0.09 \\
\hline & SD & 0.02 & 0.07 & 0.03 & 0.02 & 0.03 & 0.03 & 0.02 & 0.02 & 0.01 \\
\hline \multirow{4}{*}{$\delta^{13} \mathrm{C}(\%$ o) } & Mean & -26.7 & -27.1 & -26.9 & -20.6 & -20.9 & -19.4 & -19.5 & -15.5 & -18.9 \\
\hline & Min & -27.2 & -27.4 & -27.2 & -21.7 & -21.8 & -20.7 & -20.5 & -16.6 & -20.3 \\
\hline & Max & -26.2 & -25.9 & -26.7 & -18.7 & -19.9 & -18.6 & -16.8 & -14.4 & -17.8 \\
\hline & SD & 0.2 & 0.3 & 0.2 & 0.6 & 0.6 & 0.5 & 0.8 & 0.6 & 0.6 \\
\hline \multirow{4}{*}{$\delta^{15} \mathrm{~N}(\% \circ)$} & Mean & 0.9 & 1.3 & 0.8 & 0.9 & 0.5 & 3.9 & 3.9 & 1.8 & 2.8 \\
\hline & Min & 0.0 & -0.8 & -0.9 & -0.4 & -0.7 & 3.0 & 3.4 & 0.3 & 2.3 \\
\hline & Max & 2.4 & 2.2 & 1.4 & 2.3 & 2.0 & 4.7 & 4.7 & 3.0 & 3.3 \\
\hline & SD & 0.6 & 0.6 & 0.5 & 0.9 & 0.8 & 0.5 & 0.4 & 0.6 & 0.3 \\
\hline \multirow{4}{*}{$\mathrm{C} / \mathrm{N}$} & Mean & 16 & 21 & 18 & 9 & 10 & 8 & 8 & 9 & 7 \\
\hline & Min & 14 & 19 & 16 & 8 & 8 & 7 & 8 & 7 & 7 \\
\hline & Max & 19 & 24 & 19 & 11 & 12 & 10 & 10 & 10 & 9 \\
\hline & SD & 1 & 1 & 1 & 1 & 1 & 1 & 1 & 1 & 1 \\
\hline
\end{tabular}

TOC: total organic carbon; $\mathrm{N}$ : nitrogen; $\mathrm{C} / \mathrm{N}$ : carbon/nitrogen ratio; $\delta^{13} \mathrm{C}$ : isotopic carbon; $\delta^{15} \mathrm{~N}$ : isotopic nitrogen. Mangroves, in North to South order: M01, M02, M03. Channel, referenced by the Oceanographic buoys 106 (CS1) and 506 (CS02). Coral reefs in North to South order; the stations are Pedra de Leste (R04), Sebastião Gomes (R06), Coroa Vermelha (R07), and Nova Viçosa (R08).
Figure 6

Profiles of $\delta^{15} \mathrm{~N}$ values in the cores.

Table 1

Average values, minimum, maximum, and standard deviations of the results of elemental analysis of isotopic ratio in the cores of mangroves, channels, and reefs. 
ratio $\mathrm{C} / \mathrm{N}$ found ranged from 7.0 to 21.0. Carreira et al. (2002) have shown that in the Guanabara Bay, the $\delta^{13} \mathrm{C}$ and $\delta^{15} \mathrm{~N}$ compositions of OM varied from $-24.6 \%$ to $-19.3 \%$ o and from $+4.6 \%$ to $+8.3 \%$, respectively, and the ratio $\mathrm{C} / \mathrm{N}$ found ranged from 17.5 to 9.0. Isotopic studies conducted by Barros et al. (2010) showed that in the Babitonga Bay the $\delta^{13} \mathrm{C}$ and $\delta^{15} \mathrm{~N}$ compositions of OM varied from $-26.2 \%$ to $-21.7 \%$ and from $-0.1 \%$ o to $+9.2 \%$, respectively.

The higher positive values of $\delta^{15} \mathrm{~N}$ for the reefs are due to both the phytoplankton contribution and composition of marine OM. It corroborates the reported values for the coastal region in Brazil (Barros et al. 2010).

The results of elemental (N, TOC, and $\mathrm{C} / \mathrm{N})$ and isotopic analysis $\left(\delta^{13} \mathrm{C}\right.$ and $\left.\delta^{15} \mathrm{~N}\right)$ are shown in Figure 7 . The figure indicates that the distinction between groups represented in the diagrams coincides with the differentiation of the sampled areas. In relation to the amount of $\mathrm{OM}$ and the variation in measured isotopic values, we can infer that the obtained results are characteristic representations of mangrove environments, coastal environments (represented here by the channel that separates the southeast reef from the continent), and reef environments.

The studied parameters along the profile of the sediment cores suggest no significant changes in the sedimentary processes of the studied region due to anthropogenic interference. This confirms the results reported by Netto (2008) in the coastal region adjacent to the Abrolhos Bank.

The graph $\mathrm{N}(\%) \times$ TOC $(\%)$ (Figure 7A) illustrates two main groups: dominant marine $\mathrm{OM}(\mathrm{N}=-0.0099+0.1267$. COT, $\mathrm{r}=0.92$ ) and another with a greater amount of terrestrial OM $(\mathrm{N}=0.0549+0.0427 . \mathrm{COT}, \mathrm{r}=0.64)$. This grouping is due to the different elemental compositions because marine $\mathrm{OM}$ is richer in N. Marine samples with greater amounts OM present, relative to terrestrial ones, contain a higher content of $\mathrm{N}$, resulting in a sloped curve. In the graph of $\delta^{15} \mathrm{~N}(\% \circ) \times \delta^{13} \mathrm{C}(\%)$ (Figure $7 \mathrm{~B}$ ), it is possible to differentiate the groups due to the behavior of isotopic carbon and nitrogen. The graph $\mathrm{C} / \mathrm{N} \times$ $\delta^{13} \mathrm{C}(\%)$ (Figure 7C) illustrates that high levels of $\mathrm{C} / \mathrm{N}$ and negative values of $\delta^{13} \mathrm{C}(\%)$ denote the presence of terrestrial $\mathrm{OM}$. It is possible to see the change from terrestrial to marine environment as the samples move away from the channel. The graph $\mathrm{C} / \mathrm{N} \times \delta^{15} \mathrm{~N}(\%)$ again illustrates different groups, and the high values of $\mathrm{C} / \mathrm{N}$ and $\delta^{15} \mathrm{~N}(\% \mathrm{o})$ differentiate the OM from the mangrove reefs (Figure 7D). The value recorded for sediment core R04 is located in an intermediate position and should be investigated further.

The graphic of the principal component analysis (PCA) scores (Figure 8) shows the grouping of samples. $\mathrm{M} 01, \mathrm{M} 02$, and M03 have higher contents of $\mathrm{OM}$ (C and $\mathrm{N}$ ) and greater $\mathrm{C} / \mathrm{N}$ ratios. The additional gradient in this figure can be attributed to the greater isotopic ratio of $\delta^{15} \mathrm{~N}$ found in the differentiated channel and reef samples. This gradient of PC2 (Figure 8) increases toward R04, R06, and R07. Between R07 and R08, the gradient levels out and is greater than CS, which matches the prevalence of the NE-SW maritime current (Teixeira 2006). The R07 and R08 samples are strongly influenced by the flux of material from the CS region.
Figure 7

Diagram for the cores of mangroves; channels; and reefs.
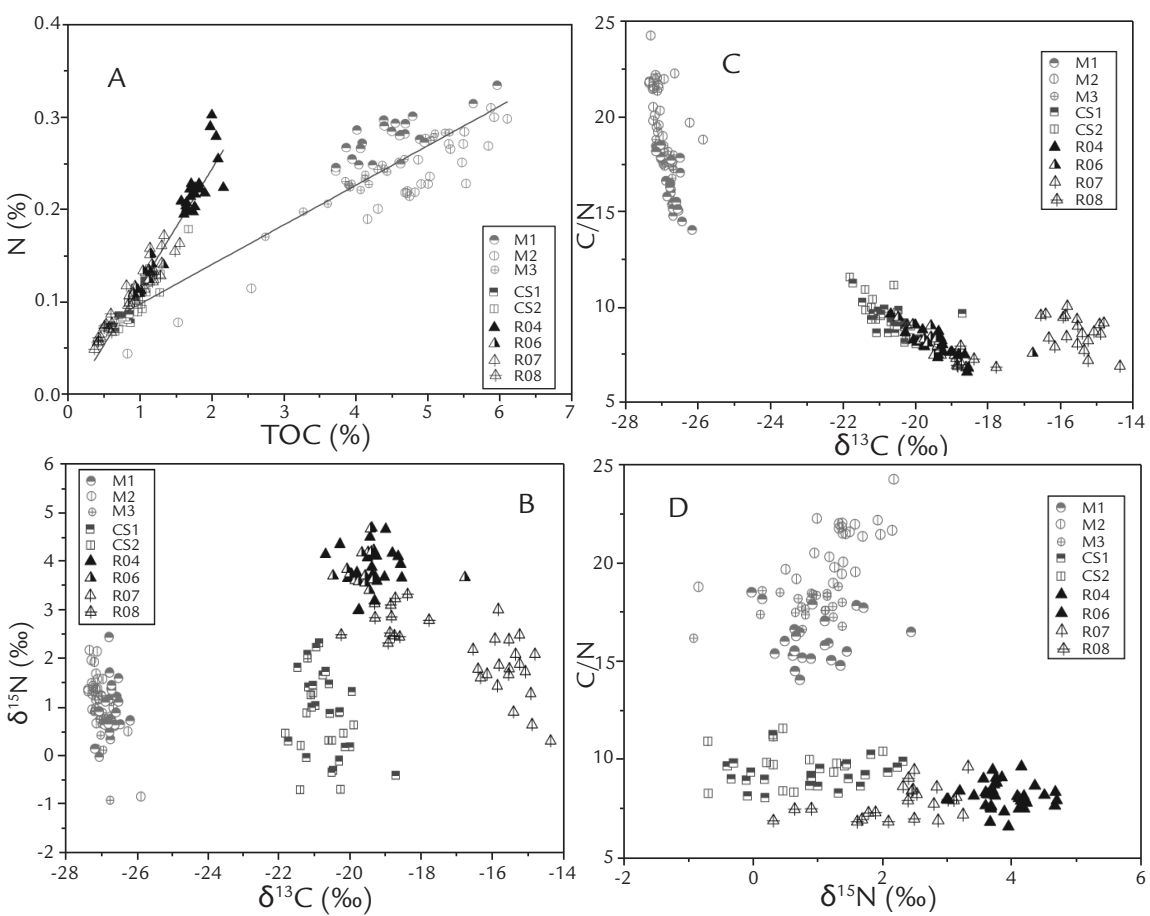

TOC: total organic carbon; $\mathrm{N}$ : nitrogen; $\mathrm{C} / \mathrm{N}$ : carbon/nitrogen ratio; $\delta^{13} \mathrm{C}$ : isotopic carbon; $\delta^{15} \mathrm{~N}$ : isotopic nitrogen. Mangroves, in North to South order: M01, M02, M03. Channel, referenced by the Oceanographic buoys 106 (CS1) and 506 (CS02). Coral reefs in North to South order; the stations are Pedra de Leste (R04), Sebastião Gomes (R06), Coroa Vermelha (R07), and Nova Viçosa (R08). 


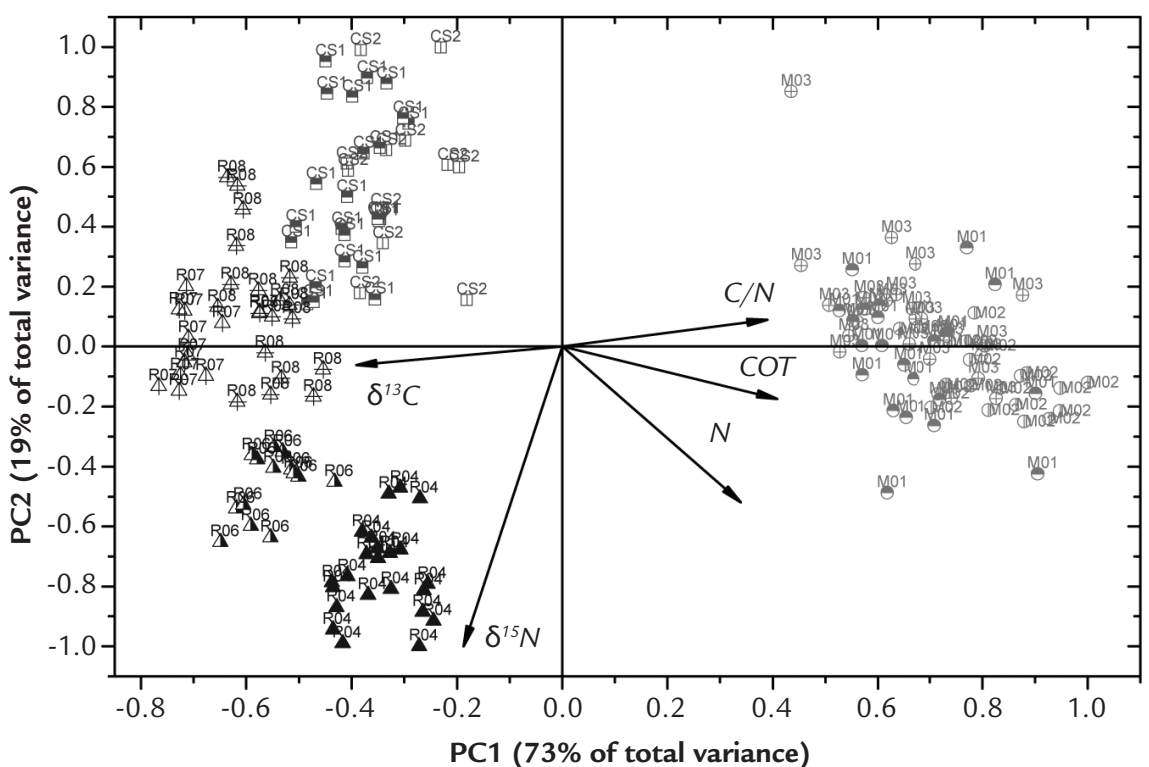

TOC: total organic carbon; $\mathrm{N}$ : nitrogen; $\mathrm{C} / \mathrm{N}$ : carbon/nitrogen ratio; $\delta^{13} \mathrm{C}$ : isotopic carbon; $\delta^{15} \mathrm{~N}$ : isotopic nitrogen. Mangroves, in North to South order: M01, M02, M03. Channel, referenced by the Oceanographic buoys 106 (CS1) and 506 (CS02). Coral reefs in North to South order; the stations are Pedra de Leste (R04), Sebastião Gomes (R06), Coroa Vermelha (R07), and Nova Viçosa (R08).
Figure 8

Scores of first principal component versus second principal component.

\subsection{Solid-state ${ }^{13}$ C NMR}

The obtained spectra for all of the sediment cores are illustrated in Figure 9. The band centered at $56 \mathrm{ppm}$, which is more prominent in mangrove samples (M01, M02, and M03), together with the band in the region between 140 and $160 \mathrm{ppm}$, is indicative of lignin, characterizing the influence of terrestrial OM. Additionally, the amount of carbon in the aliphatic range $(0-50 \mathrm{ppm})$ in the samples is indicative of $\mathrm{OM}$ found in coastal areas due to the influence of terrigenous deposits.

To aid in the analysis of the results, the multivariate curve resolution (MCR) procedure was carried out using The Unscrambler $^{\circledR} \mathrm{X}$ (CAMO Software AS) software. The basic goals of MCR are the following: the determination of the number of components coexisting in the chemical system; the extraction of the pure spectra of the components (qualitative analysis); and the extraction of the concentration profiles of the components (quantitative analysis). This analysis is preceded by principal component analysis (PCA) to estimate the number of components in the mixture. After

\section{CONCLUSIONS}

The values obtained for the $\mathrm{C} / \mathrm{N}$ ratio in mangrove areas had an average value of 18 , which is characteristic of purely terrigenous areas. In the reef environment, the mean value of the $\mathrm{C} / \mathrm{N}$ ratio was 8 , which is typical of marine and coastal regions. The results obtained for sediment cores from the channel had a mean value of 9 . This intermediate result of the $\mathrm{C} / \mathrm{N}$ ratio reflects characteristics of marine areas that are influenced by continental areas (i.e., mangroves). this, the rotation of the PC is calculated without orthonormality constraints (in this way it will have infinite solutions). To solve this, new constraints are adopted (e.g., non-negative concentrations and non-negative spectra). In this way, when the goals of MCR are achieved, it is possible to unravel the "true" underlying sources of data variation, and then the results with physical meaning are easily interpretable.

The obtained results corroborate the results of isotopic and elemental analyses; they showed different contributions of terrestrial and marine $\mathrm{OM}$ to the sediment organic composition. Because one of the components clearly originated from vascular plants, the system was modeled as a binary mixture (Figure 10): O-alkyl and di-O-alkyl (cellulose), methoxyl and aryl and O-aryl (lignin), and also alkyl and carboxyl (fatty acids). In contrast, the second component is characterized by carboxylated aromatic structures, probably carboxylate phytoplankton. Figure 11 shows the estimated concentration of the components obtained by MCR analysis of the solid-state ${ }^{13} \mathrm{C}$ NMR. 
Figure 9

${ }^{13} \mathrm{C}$ NMR spectrum for marine sediment samples. Aliphatic (0-50 ppm), methoxyl (50-60 ppm), carbohydrates (60-112 ppm), aromatic (112-160 ppm), carboxyl (160-190 ppm), and carbonyl (190-220 ppm).

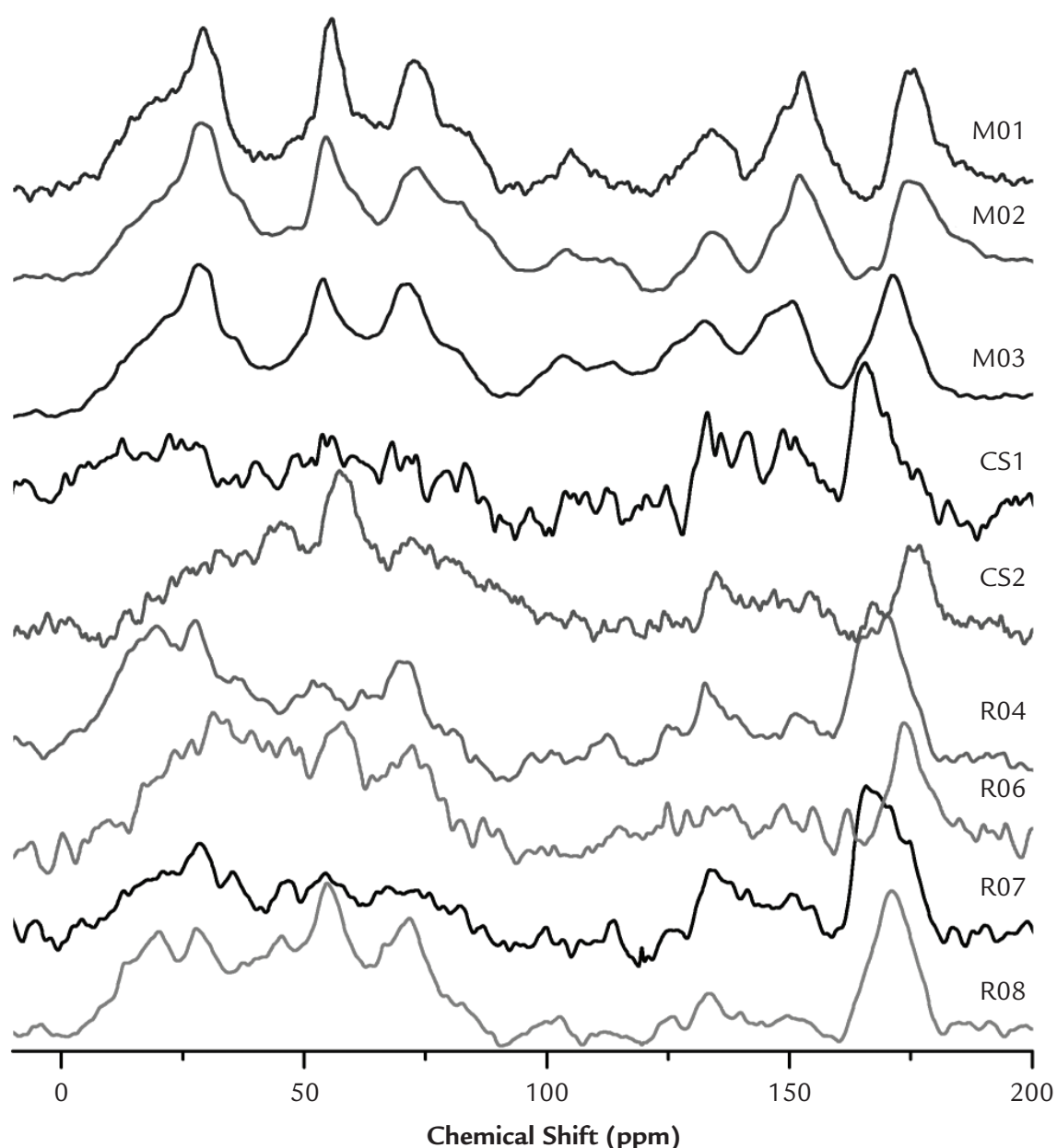

Mangroves, in North to South order: M01, M02, M03. Channel, referenced by the Oceanographic buoys 106 (CS1) and 506 (CS02). Coral reefs in North to South order; the stations are Pedra de Leste (R04), Sebastião Gomes (R06), Coroa Vermelha (R07), and Nova Viçosa (R08).
Figure 10

Estimated spectra obtained by multivariate curve resolution analysis of the solid-state ${ }^{13} \mathrm{C}$ NMR spectrum.

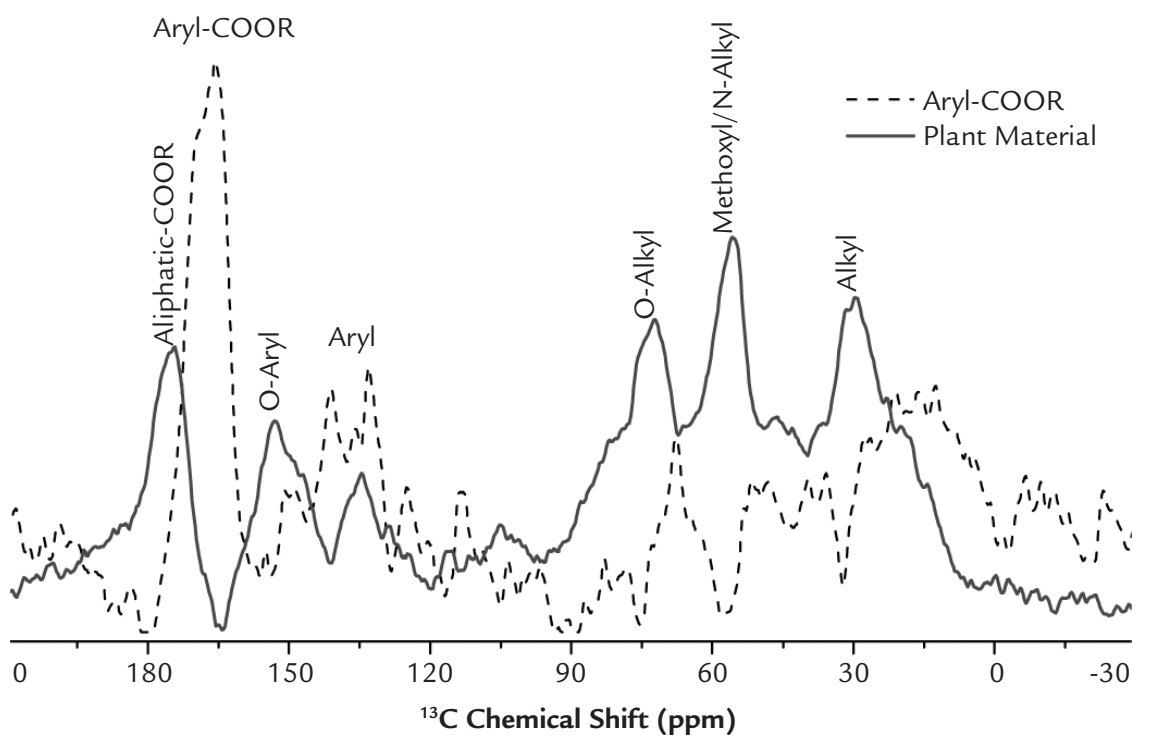




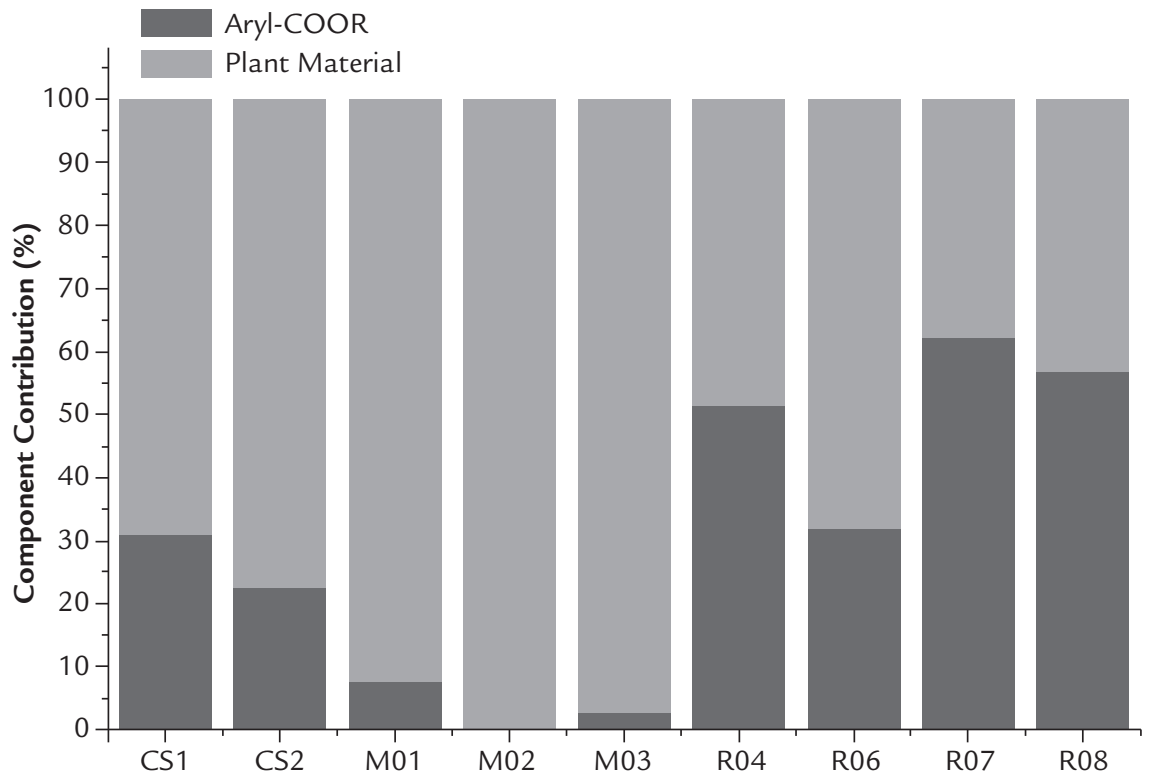

Mangroves, in North to South order: M01, M02, M03. Channel, referenced by the Oceanographic buoys 106 (CS1) and 506 (CS02). Coral reefs in North to South order; the stations are Pedra de Leste (R04), Sebastião Gomes (R06), Coroa Vermelha (R07), and Nova Viçosa (R08).
Figure 11

Estimated concentration of the components obtained by multivariate curve resolution analysis of the solid-state ${ }^{13} \mathrm{C}$ NMR spectrum. average values of $\delta^{15} \mathrm{~N}$ for the mangrove and the channel were equal to $1.0 \%$, while for the reef, it was equal to $3.1 \%$. The higher positive values of $\delta^{15} \mathrm{~N}$ for the reefs are due to both the phytoplankton contribution and composition of marine OM.

The PCA analysis shows a gradient in PC2. The gradient increases between R04, R06, and R07 and between $\mathrm{R} 07$ and R08, the gradient levels out and is greater than CS, which corroborate with the prevalence of NE-SW maritime current. The R07 and R08 samples are strongly influenced by flux of material from the CS region.
The ${ }^{13} \mathrm{C}-\mathrm{NMR}$ results confirm the data from both the isotopic and elemental analyses, showing a varying contribution of terrestrial and marine OM to the sediment organic composition.

No variations occur on the studied parameters along the profile of the sediment cores. These results indicate that anthropogenic changes on the coast did not significantly alter the composition of the material that has been deposited in the last 80 years in the Abrolhos Bank and Caravelas river estuary.

\section{REFERENCES}

Barros G.V., Martinelli L.A., Oliveira Novais T.M., Ometto J.P., Zuppi G.M. 2010. Stable isotopes of bulk organic matter to trace carbon and nitrogen dynamics in an estuarine ecosystem in Babitonga Bay (Santa Catarina, Brazil). Science of The Total Environment, 408:2226-2232.

Burone L., Muniz P., Pires-Vanin A.M.S., Rodrigues M. 2003. Spatial distribution of organic matter in the surface sediments of Ubatuba Bay (Southeastern-Brazil). Annals of the Brazilian Academy of Sciences, 75(1):77-90.

Carreira R.S., Wagener A., Readman J. W., Fileman T. W., Macko S. and Veiga A. 2002. Changes in the sedimentary organic carbon pool of a fertilized tropical estuary, Guanabara Bay, Brazil: an elemental, isotopic and molecular marker approach., Marine Chemistry, 79:207-227.

Deines P. 1980. The isotopic composition of reduced organic carbon. In: P. Fritz \& J. Ch. Fontes (eds.) Handbook of Environmental Isotope Geochemistry. Volume 1: The Terrestrial Environment, Elsevier Science Ltd, p. 329-406.

Gélinas Y., Baldock J.A., Hedges J.I. 2001. Demineralization of marine and freshwater sediments for CP/MAS 13C NMR analysis. Organic Geochemistry, 32:677-693.

Guo L., Tanaka T., Wang D., Tanaka N., Murata A. 2004. Distributions, speciation and stable isotope composition of organic matter in the southeastern Bering Sea. Marine Chemistry, 91:211-226. 
Hatcher P., Rowan R., Mattingly M.A. $1980 .{ }^{1} \mathrm{H}$ and ${ }^{13} \mathrm{C}$ NMR of marine humic acids. Organic Geochemistry, 2:77-85.

Hedges J. \& Oades J. 1997. Comparative organic geochemistries of soils and marine sediments. Organic Geochemistry, 27:319-361.

Hedges J.I., Keil R.G., Benner R. 1997. What happens to terrestrial organic matter in the ocean? Organic Geochemistry, 27:195-212.

Martinelli L.P., Ometto J.P.H.B., Ferraz E.S., Victoria R.L., Camargo P.B., Moreira M.Z. 2009. Desvendando Questões Ambientais com Isótopos Estáveis. Oficina de Textos, São Paulo.

Meksumpun S., Meksumpun C., Hoshika A, Mishima Y, Tanimoto T. 2005. Stable carbon and nitrogen isotope ratios of sediment in the gulf of Thailand: Evidence for understanding of marine environment. Continental Shelf Research, 25:1905-1915.

Nagel B., Gaye B., Kodina L.A., Lahajnar N. 2009. Stable carbon and nitrogen isotopes as indicators for organic matter sources in the Kara Sea. Marine Geology, 266:42-51.

Netto M.A. 2008. Modificações da Zona Costeira do Extremo Sul da Bahia nos últimos 150 anos, e sua relação com a sedimentação do banco de Abrolhos. Tese de Doutorado, Curso de Pós-Graduação em Geologia, Área de Geologia Marinha, Costeira e Sedimentar. Instituto de Geociências, Universidade Federal da Bahia.

Ogrinc N., Fontolan G., Faganeli J., Covelli S. 2005. Carbon and nitrogen isotope compositions of organic matter in coastal marine sediments (the Gulf of Trieste, N Adriatic Sea): indicators of sources and preservation. Marine Chemistry, 95:163-181.

Ryba S.A., Burgess R.M. 2002. Effects of sample preparation on the measurement of organic carbon, hydrogen, nitrogen, sulfur and oxygen concentrations in marine sediments. Chemosphere, 48:139-147.

Saito Y., Nishimura A., Matsumoto E. 1989. Transgressive sand sheet covering the shelf and upper slope off Sendai, Northeast Japan. Marine Geology, 89:245-258.

Sampaio L., Freitas R., Máguas C., Rodrigues A., Quintino V. 2010. Coastal sediments under the influence of multiple organic enrichment sources: An evaluation using carbon and nitrogen stable isotopes. Marine Pollution Bulletin, 60:272-282.

Stein R. 1991. Accumulation of organic carbon in marine sediments. Results from the deep sea drilling project/ocean drilling program. Lecture Notes in Earth Sciences, 34, 217 p.

Teixeira C.E.P. 2006. Caracterização e Variabilidade da Hidrodinamica da Zona Costeira Adjacent ao Banco dos Abrolhos. Dissertação de Mestrado, Instituto Oceanográfico, Universidade de São Paulo, 93 p.

Tesi T., Miserocchi S, Goñi M.A., Langone L., Boldrin A., Turchetto M. 2007. Organic matter origin and distribution in suspended particulate materials and surficial sediments from the western Adriatic Sea (Italy). Estuarine, Coastal and Shelf Science, 73:431-446.

Usui T., Nagao S., Yamamoto M., Suzuki K., Kudo I, Montani S., Noda A., Minagawa M. 2006. Distribution and sources of organic matter in surficial sediments on the shelf and slope off Tokachi, western North Pacific, inferred from $\mathrm{C}$ and $\mathrm{N}$ stable isotopes and $\mathrm{C} / \mathrm{N}$ ratios. Marine Chemistry, 98:241-259. 